\title{
Plant economy and territory exploitation in the Alps during the Neolithic (5000-4200 cal BC): first results of archaeobotanical studies in the Valais (Switzerland)
}

\author{
Lucie Martin
}

Received: 26 December 2013/ Accepted: 6 October 2014/Published online: 15 October 2014

(c) Springer-Verlag Berlin Heidelberg 2014

\begin{abstract}
This paper presents the archaeobotanical study of several Neolithic settlements located in the Valais, the upper part of the Rhone Valley, in Switzerland. The archaeological sites are dated between 5000 and 4200 cal $\mathrm{BC}$, which corresponds to the Early and the Middle Neolithic. Most of the sites are situated around 500-600 m, overhanging the alluvial plain of the Rhone. First results of the macroremains analysis show that cereals, comprising mainly naked wheat (Triticum aestivum s.1./durum/turgidum) and barley (Hordeum distichum/vulgare), are predominant. In addition, pea (Pisum sativum) and opium poppy (Papaver somniferum) are recorded. Gathered plants are sparse, and this from the first establishment of farmers around $5000 \mathrm{cal}$ BC. If we compare the obtained results with data from the Northern French Alps, not far from the Valais, we get a completely different picture of the Neolithic plant economy. In the northern French Alps the communities exploited all vegetation levels from the collinean to the subalpine belt, gathered plants playing an important role alongside the cultivated species. Our first results are giving a new insight into the first agro-pastoral communities in the Swiss Alps; they are allowing us to understand how plant resources were exploited in a
\end{abstract}

Communicated by S. M. Valamoti.

L. Martin $(\square)$

Laboratory of Prehistoric Archaeology and Anthropology, Institut F. A. Forel, Sciences de la Terre et de l'Environnement, Université de Genève, 18 route des Acacias, 1211 Genève 4, Switzerland

e-mail: lucie.martin@unige.ch

L. Martin

EDYTEM, Université de Savoie, CNRS Pôle Montagne,

73376 Le Bourget Du Lac, France mountainous context and to outline the catchment area of the settlements.

Keywords Swiss Alps · Valais - Neolithic · Plant macroremains · Diet · Exploitation of territory

\section{Introduction}

This paper is presenting the first results of an ongoing project that focuses on archaeobotanical studies of twenty Neolithic sites in the canton of Valais in Switzerland. The first results from five of these sites, which have been the subject of preliminary studies by the late K. Lundström-Baudais, will be presented. The canton of Valais is situated in the upper part of the Rhone valley in the Swiss Alps, between the Rhone glacier, where the river has its source, and Lake Geneva. This wide valley comprises numerous tributaries; mountains up to 4,500 $\mathrm{m}$ high surround it (Fig. 1). Sheltered from depressions coming from the Atlantic or from the Mediterranean, the Valais is characterised by a continental climate with high sunshine and low precipitation (between 600 and 1,000 mm/year in the Rhone valley).

Environment and human occupation of the Valais during the Neolithic

A number of timberline studies exist from the region (e.g. Finsinger and Tinner 2007; Haas et al. 1998; Heiri et al. 2006), but we have no palynological analyses for the Rhone valley bottom, except from the Lake Mont d'Orge in Sion (Welten 1982; Colombaroli et al. 2012). During the Early Atlantic (6900-4700 cal BC) the landscape in the lower plains was dominated by Pinus (pine) and Quercus pubescens (pubescent oak), and by dense broadleaf forests at an 
altitude of 700-800 m. Fagus (beech) migrated into the region, but never extended widely in the western part of the Valais. Abies alba (silver fir) grew at altitude on northern slopes and in the western part of the Rhone Valley. During the Late Atlantic (4700-3400 cal BC), Picea (spruce) and Alnus viridis (green alder) spread in the Valais. The development of these two species is probably due either to climate changes, notably the "Rotmoos I" deterioration around $3800 \mathrm{cal} \mathrm{BC}$, or to human impact on vegetation. Land clearances at altitude favoured Alnus viridis, a pioneer species (Corboud et al. 2008; Richoz and Haas 1995).

The Valais has a long tradition of archaeological investigations from the 1950s onwards, through the work of several researchers from the University of Geneva (Curdy 2007; Gallay 2008). Excavations, coupled with field survey programmes (e.g. the programme "Archaeological prospections in the Valais and the Chablais", Baudais et al. 1989, 1990), permitted the construction of a good chronocultural framework in this region. About 40 Neolithic sites, mainly settlements, but also graves and isolated discoveries, are known in this region.

The first agro-pastoral communities settled in the actual town of Sion around $5300 \mathrm{cal}$ BC. The only known occupation at altitude from the Early Neolithic is "Alp Hermettji", a rock shelter near Zermatt at 2,600 m a.s.l. (Curdy et al. 2003). During the same period, the first land clearance and cereal pollen are recorded in the lake of Mont d'Orge in Sion (Fig. 1, Colombaroli et al. 2012), as well as the first evidence of animal husbandry, especially

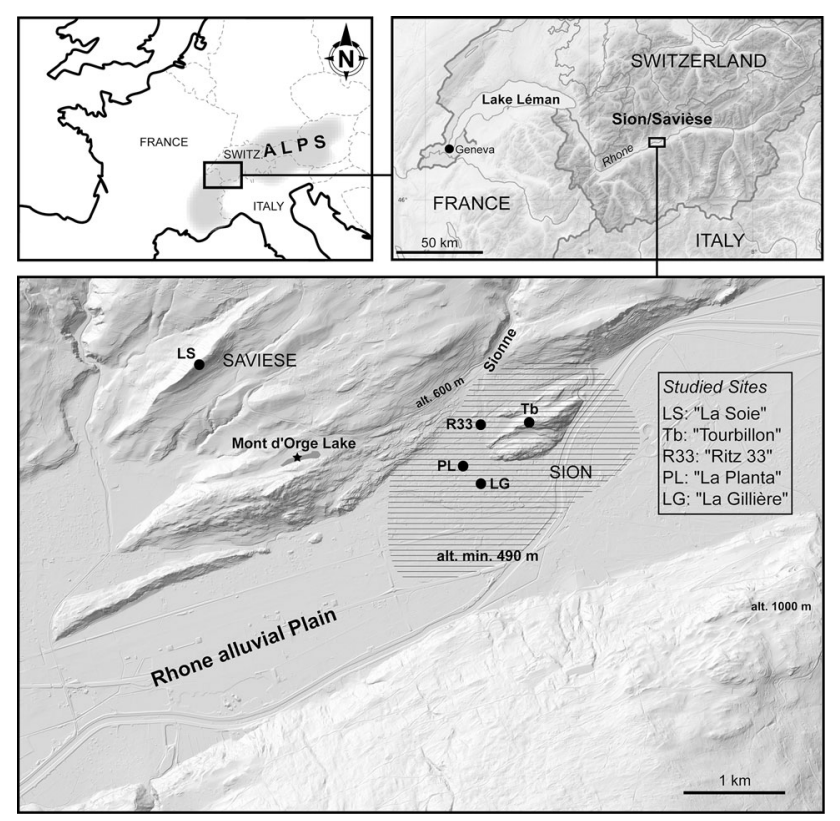

Fig. 1 Map showing the position of the Valais in the Western Alps, and the location of the six studied sites in Sion and Savièse. Shading represents the town of Sion of sheep and goats (Chaix 2008). At the beginning of the Middle Neolithic, between 4700 and 4000 cal BC, cultural influences come mainly from the Swiss Plateau and the Jura massif, but also from the Middle Rhone Valley and Northern Italy (Denaire et al. 2011).

\section{Studied sites}

The data presented come from five sites. Four are situated in the town of Sion, between 500 and $650 \mathrm{~m}$ a.s.l. and one in Savièse at $850 \mathrm{~m}$ a.s.l. All of them are located on the south-facing slope, near the alluvial plain or on the top of rocky hills (Fig. 1).

The sites in Sion are:

"La Planta", excavated in 1980 by A. Gallay, R. Carazzetti and C. Brunier. The excavated surface (about $300 \mathrm{~m}^{2}$ ) revealed one of the oldest Neolithic settlement in the Alps, with many structures such as hearths, pits and post holes (Gallay et al. 1983)

"Tourbillon", excavated in 1994 by C. Müller. Situated on a berm on the hill of Tourbillon, a survey of $4 \mathrm{~m}^{2}$ yielded layers with decorated pottery, similar to pottery from the Early Neolithic in Northern Italy (Müller 1995)

"La Gillière" excavated between 1991 and 1993 by P.Y. Schmidt and D. Baudais. The site comprises a settlement with numerous pits, a big hearth and several graves (Baudais and Schmidt 1995)

"Ritz 33", excavated in 1987-1988 by D. Baudais and P. Moinat. An important cemetery and a settlement characterized this deposit (Baudais et al. 1989, 1990).

Finally, in Savièse, D. Baudais excavated the site of "La Soie" in 1993-1994. It is situated on the western part of the hill of La Soie, above the town of Sion.

Excavations revealed several settlements from the Middle and Late Neolithic (Baudais 1995). All the studied samples are radiocarbon-dated to between 5300 and $4200 \mathrm{cal} \mathrm{BC}$, covering the early Neolithic and the beginning of the Middle Neolithic (Fig. 2).

\section{Materials and methods}

Despite the fact that the studied sites were excavated quite a long time ago, between 1980 and 1994, fortunately they were all sampled in order to perform archaeobotanical studies. However, sample volumes differ widely among the different sites, varying between 81 and more than $500 \mathrm{~kg}$. As to the origin of the samples, most of them were taken from occupation layers or structures like pits and hearths (Table 1). All samples were wet-sieved with a minimum mesh of $0.5 \mathrm{~mm}$. Residues were dried and stored in plastic boxes for further analyses. Seeds, fruits and other plant macroremains were identified using the modern reference 


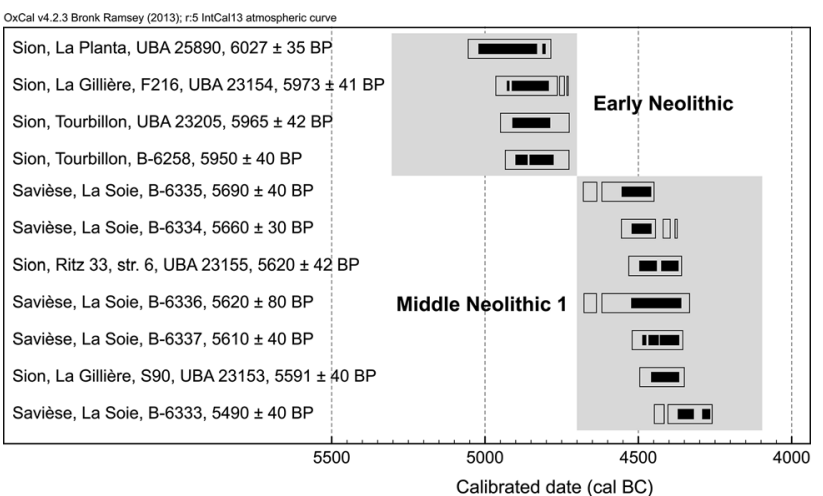

Fig. 2 Radiocarbon dates from the studied sites. Radiocarbon dates are calibrated (two sigma) with Oxcal 4.1. (Reimer et al. 2013)

collection of K. Lundström-Baudais and of the Integrative Prehistory and Archaeological Sciences (IPAS) at Basel University, as well as seed atlases (e.g. Cappers et al. 2006; Jacquat 1988). In this paper, we follow the taxonomy and nomenclature from Aeschimann and Burdet (1994) and from Jacomet et al. (2006) for the cereals.

\section{Results}

Sion, "La Planta"

A total of 693 remains were recovered in "La Planta". They derive from five samples dating to the end of the Early Neolithic (Fig. 2). 27 taxa were identified, ten of these to species level. All plant macroremains were charred; their preservation was on average bad; 102 remains could not be identified while many items $(n=312)$ were identified only to the level of family. The density of remains within the samples varies between 0.1 and 32.7 items per $\mathrm{kg}$, with an average of 9.4 items $/ \mathrm{kg}$ (Table 1). In the assemblage several groups of plants can be distinguished. The first one comprises Cerealia-type (cereals), including Triticum aestivum s.1./durum/turgidum-T. nudum (naked wheat) for short-with only five caryopses (Table 1). The second group comprises wild plants and mainly weeds like Chenopodium album (fat-hen), Fallopia convolvulus (black-bindweed), Galium aparine/spurium (cleavers/false cleavers) with single seeds of Papaver $d u$ bium (long-headed poppy), of Polygonum lapathifolium/ persicaria (pale persicaria or redshank) and a possible find of Vicia hirsuta (hairy tare). This group also includes two seeds of Atropa bella-donna (deadly nightshade), a species that grows principally in clearings and forest edges. Only one possible seed fragment of Cornus sanguinea (common dogwood) and one shell fragment of Corylus avellana (hazel) represent ligneous species. Finally many of the wild plants cannot be identified to a species level and can thus not be attributed to a specific group (Table 1).

Sion, "Tourbillon"

772 charred plant remains were recovered from three samples dated to the Early Neolithic, and from four pits dated to the Early/Middle Neolithic. 18 taxa were identified of which eight were to species level. The density of remains within the samples varies between 0.6 and 23.4 items per litre, with an average of 5.8 (Fig. 3). The assemblage is dominated by cereals, which represent more than $75 \%$ of the total $(n=587)$. Cereals are not very well preserved, very fragmented, and more than half of them are identified as Cerealia-type, Triticum/Hordeum or caryopses with morphology between emmer and naked wheat (Triticum dicoccum/aestivum s.1./durum/turgidum). The dominant species is naked wheat, followed by barley (Hordeum distichum/ vulgare) and by a single seed of emmer. Cereals are generally all mixed in the samples. Opium poppy (Papaver somniferum), with only five seeds, completes the spectrum of domesticated plants. For trees and shrubs, we have identified one twig fragment of Pinaceae and four shell fragments of hazel. The weeds comprise three species: Chenopodium album, Fallopia convolvulus and Vicia hirsuta/tetrasperma (hairy/four-seeded vetch). Beyond these the assemblage is composed of seeds not identifiable to species level (Table 1).

\section{Sion, "La Gillière"}

From this site two samples were studied. The first one is from a hearth (F216), and is dated to the end of the Early Neolithic; the second one comes from the fillings of a pit (S90) and is dated to the Middle Neolithic. The hearth (F216) revealed 25,471 charred plant remains. 17 taxa were identified of which nine were to species level. The density of remains is 340 items per $\mathrm{kg}$ (Table 1). The assemblage is widely dominated by domesticated plants. Cereals, which represent almost $70 \%$ of the remains, including only $0.2 \%$ of chaff, are mainly Cerealia-type, Triticum/Hordeum and Triticum sp. Amongst the identified species mixed in the sample, naked wheat is the most important cereal, followed by barley, emmer and a group of caryopses with morphology between emmer and naked wheat; chaff of wheat and barley is sparse. Beside the cereals, a large number of opium poppy seeds are present (Table 1). Hazelnut shell fragments and a single pip of Pyrus communis (wild pear) represent the ligneous species. The only attested weeds are ruderal, namely Chenopodium album and a single seed of Hyoscyamus niger (henbane). The assemblage also comprises several other wild taxa (Table 1).

For structure S90, 238 items and 15 taxa were registered, all of which were charred. The density of remains is 


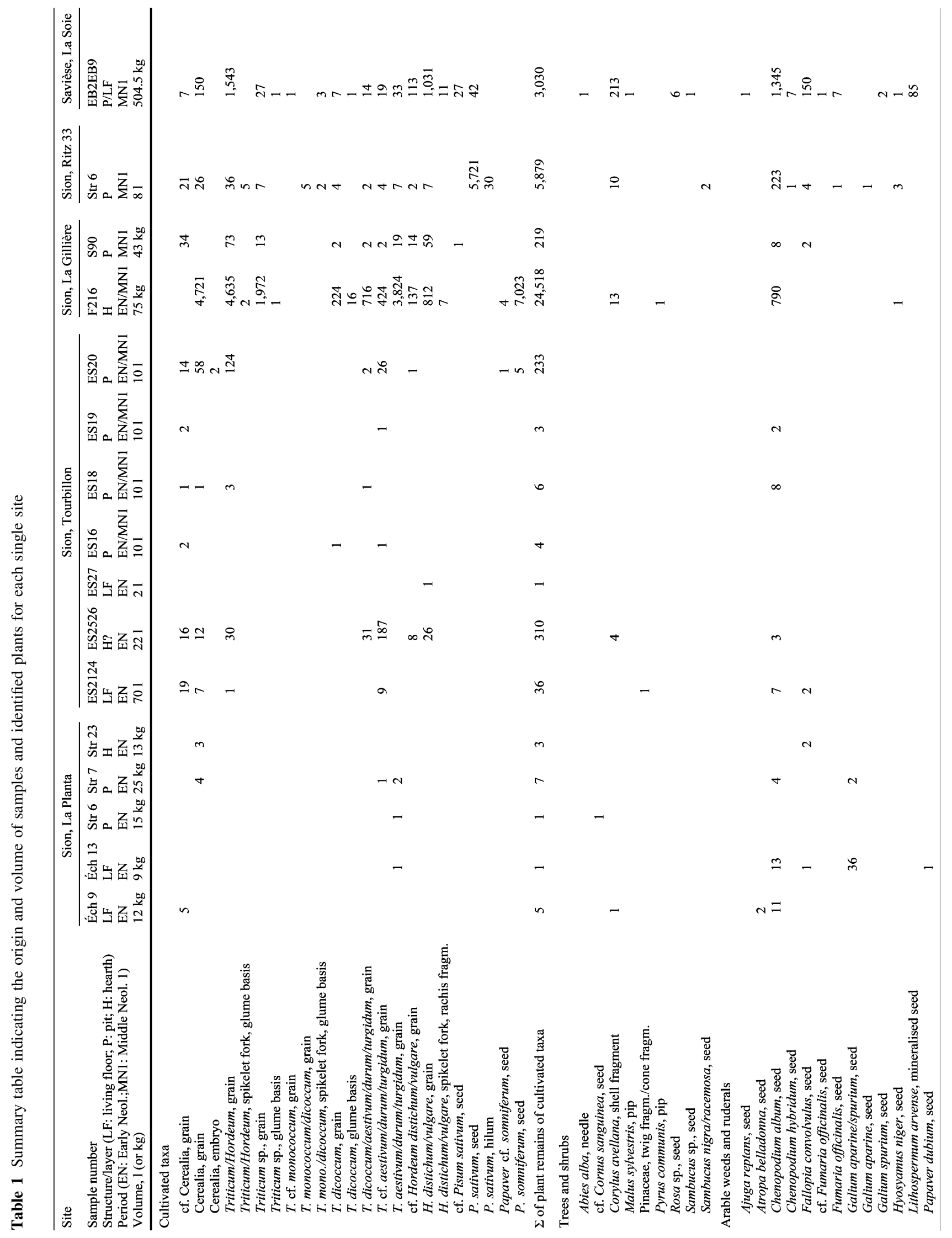




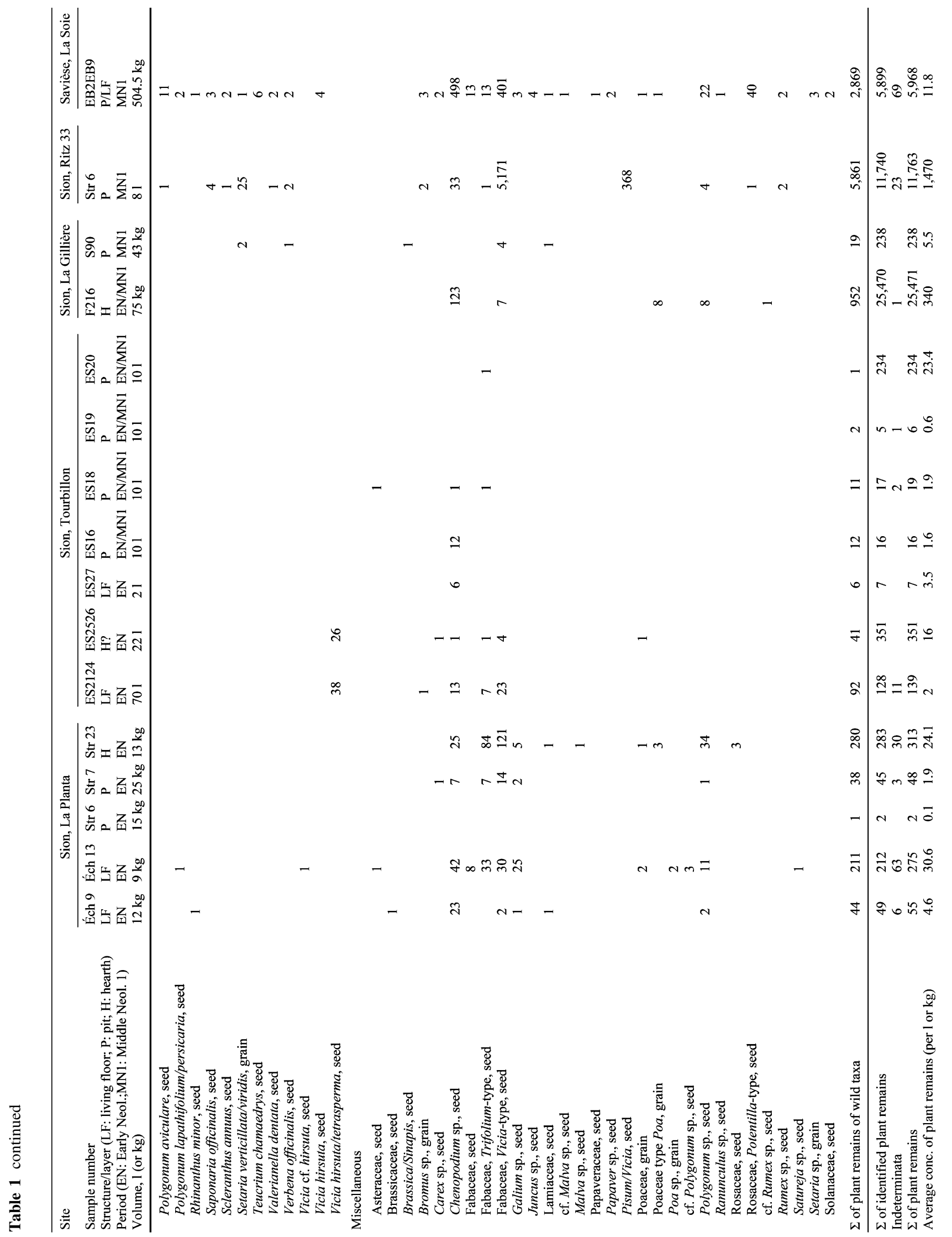




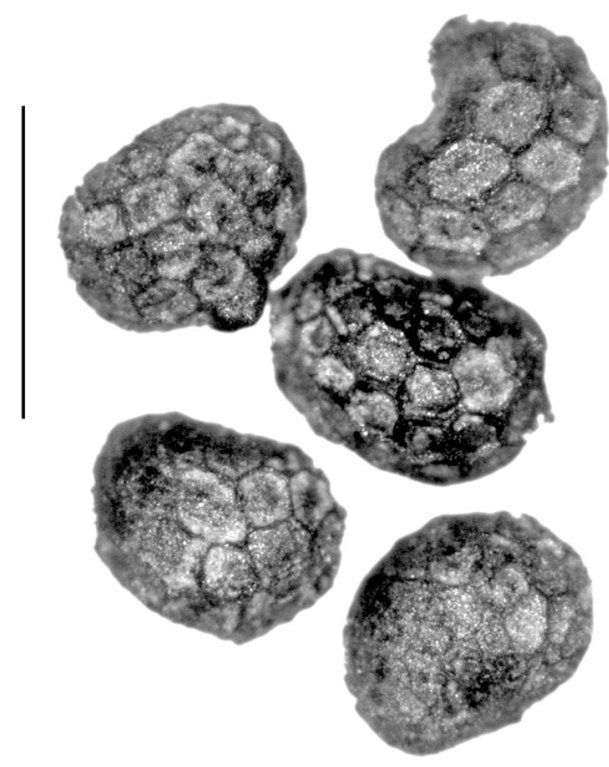

Fig. 3 Seeds of Papaver somniferum (opium poppy) found in Sion "La Gillière", 4980-4730 cal вс, scale $1 \mathrm{~mm}$

5.5 items per $\mathrm{kg}$. In this structure, half of the cereals could not be identified in detail (Cerealia type and Triticum/ Hordeum). Cereals are mixed, but among them, barley caryopses are predominant, followed by naked wheat and emmer. Chaff remains are absent. One seed, maybe of Pisum sativum (pea), completes this crop spectrum. In the group of weeds and ruderals, Brassica/Sinapis (cabbage/ mustard), Chenopodium album, Fallopia convolvulus, Setaria verticillata/viridis (bristlegrass) and Verbena officinalis (common vervain) were recorded. Some wild taxa were also found (Table 1).

\section{Sion, "Ritz 33"}

From this site, one sample of 81 coming from a probable storage pit, dated to the Middle Neolithic, delivered 11,763 charred plant remains. The density of remains is high, with 1,470 items per litre. The sample is composed of 5,721 seeds of pea, to this another 5,171 probable seeds of pea (hilum is missing) and 368 smaller seeds identified as $\mathrm{Pi}$ sum/Vicia can be added. This group of pulses represents more than $92 \%$ of the assemblage. The remaining taxa are cereals, trees, weeds and ruderals as well as taxa that cannot be identified to species level. Among the cereals (2.1\% of total plant remains), mainly Cerealia-type, Triticum/Hordeum and Triticum sp. were recorded, however five caryopses and two glume bases of T. monococcum/T. dicoccum (einkorn/emmer), four caryopses of emmer, two caryopses of emmer or naked wheat, seven caryopses of naked wheat and seven caryopses of barley were also registered (Table 1). Ten shell fragments of hazel and two seeds of Sambucus nigra/racemosa (black/red elder) represent the trees. The weeds and ruderals group contains Ch. album, Fallopia convolvulus, Hyoscyamus niger, Saponaria officinalis (soapwort), S. verticillata/viridis and Verbena officinalis. This group also includes single items of Ch. hybridum (maple-leaved goosefoot), Fumaria officinalis (common fumitory), Galium aparine, Polygonum aviculare (birdgrass), Scleranthus annuus (annual knawel) and Vallerianella dentata (narrow-fruited cornsalad). We also identified several taxa not identifiable to species level (Table 1).

Savièse, "La Soie"

The archaeological analysis concentrated on a layer, dated to the Middle Neolithic, comprised of four pits and a living floor. The five samples delivered a total of 5,968 plant macroremains. These are charred except for Buglossoides arvensis (field gromwell) that is mineralised. The volume of the samples reaches more than $500 \mathrm{~kg}$. The average concentration of remains is 11.8 per $\mathrm{kg}$ (Table 1). With 53 taxa, including 28 species, this assemblage has the biggest diversity within the five studied sites. It is composed of domesticated plants, trees and shrubs, weeds and ruderals, and plants from meadows and grasslands. The domesticated plants are dominated by cereals, of which almost $60 \%$ are not precisely identified, due to fragmentation (Cerealia-type, Triticum/Hordeum and Triticum sp.). The remaining, mixed, are dominated by barley grains (38\% of cereals remains), with, in smaller quantities, possible einkorn ( $T$. cf. monococcum), a few spikelet forks and glumes bases of einkorn/emmer, caryopses and glume bases of emmer, and naked wheat (Table 1). Pea also completes the crop spectrum (Fig. 3). Trees and shrubs are present with many hazel shell fragments, a needle fragment of silver fir, a wild apple pip (Malus sylvestris), six rose seeds (Rosa sp.) and a seed of elder (Sambucus sp.). Arable weeds and ruderals are mainly represented by $C h$. album and Fallopia convolvulus, as well as many other species listed in Table 1. A last group comprises taxa represented by a single item, not identifiable to species level (Table 1).

\section{Discussion}

Cultivated plants

\section{Cereals}

The five studied sites revealed the presence of domesticated plants, such as cereals, comprising several wheat species-einkorn, emmer and naked wheat-and barley, mainly recorded as caryopses. For a total of 21,953 grains, 
only 49 chaff remains (spikelet forks, glume bases and rachis segment) of wheat and barley $(0.2 \%)$ were found. Cereals came from different structures such as living floors, hearths or pits. For these last, it is hard to say if pits were used for storage, because cereals were not found in large concentrations. For example, in "La Planta" seven items in Str. 7 from $25 \mathrm{~kg}$ of sediment, in "Tourbillon" 233 cereals in 101 of sediment from pit ES20 and in "La Gillière" 219 remains in $43 \mathrm{~kg}$ of sample from pit $\mathrm{S} 90$ were found. Anyway, cereals were an important part of the diet among these prehistoric populations. They represent between $50 \%$ and more than $90 \%$ of the total number of remains for three of the studied sites: "Tourbillon", "La Gillière" and "Ritz 33". In "La Planta", only low numbers of cereals were counted $(n=17)$, and in "Ritz 33", 805 cereal remains were identified within a pea stock comprising thousands of seeds. Cerealia type, Triticum/Hordeum and Triticum sp. often represent 40-60\% of the cereal assemblage. Nevertheless a first insight into the cereal distribution can be obtained.

Only caryopses were found of naked wheat, therefore the ploidy level remains unknown. For barley, preservation did not allow the precise determination of its hulled and/or naked form, as well as its two-rowed/many-rowed form. However, in "La Soie", naked barley could be recognized through the presence of wavelets on the caryopses, as well as a few asymmetric grains, which indicate the presence of a many-rowed barley form.

Early Neolithic (5000-4700 cal BC): Naked wheat is predominant during the Early Neolithic. In "La Planta", there are only a few caryopses, however they indicate only naked wheat; in "Tourbillon" and in "La Gillière", naked wheat is predominant. In the latter, barley appears as well as emmer. Beside cereals, "La Gillière" delivered a single possible seed of pea (cf. Pisum), and many remains of opium poppy (see next section of the discussion).

Comparing our results with other data from the western Alps and its surroundings, we stress that most of the studies were done around the massif, and especially in the north, on the Swiss Plateau. Unfortunately, during the Early Neolithic such settlements are not known. In the Alps and its surroundings, only a dozen sites provided archaeobotanical studies, many without quantitative data. However, they indicate the presence of barley, and einkorn, emmer and naked wheat (Martin 2014, p 57). In the western part of Central Europe (Eastern Austria and Germany), during the second phase of expansion of Linearbankeramik Culture (5200-4900 cal BC), it is interesting to observe that einkorn and emmer widely predominate (Jacomet 2007; Kohler-Schneider 2007; Kreuz 2007; Kreuz et al. 2005). In the south of the Alps (Spain, France and Italy), naked wheat and barley are the most important cereals, whereas einkorn and emmer are secondary crops (Buxó 2007; Marinval 2008; PeñaChocarro 2007; Rottoli and Pessina 2007). Our archaeobotanical data show that the spectrum of cereals cultivated by the first farmers in the Valais is different from Bandkeramik assemblages, and more related to the south of the Alps, especially Southern France and Northern Italy. Even if archaeological material for this period is poorly preserved in the Valais, it supports our results: for example, ceramics from "Tourbillon" show affinities with the Isolino group, an Early Neolithic Culture in northern Italy (Müller 1995).

Middle Neolithic (4700-4100 cal BC): During the Middle Neolithic in the Valais, between 4500 and $4000 \mathrm{cal} \mathrm{BC}$, barley seems to be more important than naked wheat in "La Soie" as well as in "La Gillière", even if these two samples are not quantitatively representative. In "La Gillière", the sample from S90 is quite poor, with 219 cereals remains for a volume of $43 \mathrm{~kg}$. In "La Soie", cereals were badly preserved and more than the half were identified as Triticum/Hordeum (Table 1). Moreover, naked wheat remains important in "Ritz 33". Among other domesticated plants, two sites provided remains of pea: "La Soie" with 42 certain and 27 possible identifications cf. Pisum, and "Ritz 33" in particular, with 5,763 seeds of pea, in a container made of bark which indicates its storage.

For the Middle Neolithic 1 (MN1), naked wheat and barley are the main cereals cultivated by the first piledwellers on the Swiss Plateau, as well as in northern Italy (Martin 2014, p 58). In the Alps, few data are available for the MN1. In northern French Alps, at the site of "Le Chenet des Pierres", barley predominates (284 grains of barley versus 92 remains of wheat, including chaff), despite the relatively bad conservation of cereal remains (1,184 grains of Cerealia; Martin et al. 2008). In the shelter of "l'Aulp du Seuil", a hunting camp dated between 4450 and $4250 \mathrm{cal}$ вС, few cereals were found $(n=37)$ but einkorn, naked wheat and barley were identified (Martin et al. 2012). This corresponds well with our data from the Valais. On the contrary, in Austria and Southern Germany, between 5000 and $4300 \mathrm{cal}$ BC, einkorn and emmer continue to be the most important cereals. Naked wheat is found in higher numbers and barley seems to have had greater importance. Pea, which has been found in large quantities at "Ritz 33", is almost always represented in and around the Alps, but often in low quantities (Jacomet 2007; Kohler-Schneider 2007; Kreuz et al. 2005). Here again, the spectrum of cultivated plants is different, between the Alps/ Swiss Plateau and Central Europe, even if we have few emmer grains in "La Gillière". In the Valais, none of the studied sites provided well preserved artefacts, but we believe that alpine populations were still close to the 
Mediterranean area, as shown also by the presence of opium poppy and some weeds (see below).

\section{The case of Papaver somniferum}

Another interesting cultivated plant is $P$. somniferum (opium poppy). This food plant is used for the oil contained in its seeds and also has medicinal properties (Duke 1973). In the Valais, we found it at two sites: "Tourbillon" dated to $4950-4730$ cal BC with a single seed and possibly five others and at "La Gillière" dated to 4980-4730 cal BC with a large number of seeds $(n=7,033$, Fig. 3$)$. For this period, there is no evidence of $P$. somniferum in Northern Italy and on the Swiss Plateau, where waterlogged settlements are still non-existent. P. somniferum is recorded in large quantities in Linearbandkeramik sites during the second phase (LBK II), around 5200-5000 cal вC. In contrast in southern Europe discoveries of Papaver, contemporary with LBK II sites, and until $4500 \mathrm{cal} \mathrm{BC,} \mathrm{are} \mathrm{very} \mathrm{sporadic.}$ It occurs at three sites in Spain and "La Marmotta" in Central Italy, the only site that yielded this species in this country for the Early Neolithic (Kreuz et al. 2005; Rottoli and Pessina 2007). Salavert (2010) proposes the hypothesis that $P$. somniferum did not arrive in North-western Europe as a cultivated form but as a weed. In the Valais, on one hand, the presence of Papaver supports the fact that first farmers in the Alps could have come from Northern Italy, given that it is known that wild poppy (Papaver somniferum ssp. setigerum) originates from the western and central Mediterranean. On the other hand, contrary to the difference of cereal assemblages between the Alps/the Swiss Plateau and Central Europe, discoveries of $P$. somniferum in the Valais could suggest a connection with LBK communities. The lack of archaeobotanical studies for the Early Neolithic period in South-western Europe does not help in understanding the position of $P$. somniferum in this area. In any case, with these first early discoveries in the region, further analyses (in the Alps and their surroundings) are necessary to refine and understand the spread and evolution of this species in Western Europe. The Valais indeed lies between the supposed area of domestication of $P$. somniferum and the regions where it was first widely cultivated.

Weeds and agricultural practices

As mentioned before, cereals were found almost entirely in the form of grain at all sites (chaff representing a total of just $0.2 \%$ ). The composition of our assemblages shows that cereals were ready to be stored and used. Considering the absence of chaff and of spherulites in the samples, we do not consider the possibility they might include dung remains. In our assemblages numerous arable weeds were found, together with cereals. We assume that these species are arable weeds and/or ruderals according to Ellenberg (1988), Julve (1998), Kreuz et al. (2005). Ch. album and Fallopia convolvulus are identified at all sites in great quantities. Many other species were also recorded, such as Ch. hybridum, Fumaria officinalis, Galium aparine/spurium, G. spurium, Buglossoides arvensis, Papaver dubium, Polygonum aviculare, Polygonum lapathifolium/persicaria, Scleranthus annuus, S. verticillata/viridis, Valerianella dentata, Vicia hirsuta and V. hirsuta/tetrasperma. The spectrum of arable weeds gives evidence about agricultural practices, even if some of them could be also ruderals (e.g. Ch. album or Polygonum lapathifolium). Firstly, we point out the presence of Mediterranean species like Scleranthus annuus, Papaver dubium and Buglossoides arvensis, which confirms the hypothesis of the southern origin of the first farmers in this region. The continental climate of the region permitted these species to settle in this alpine valley. Secondly, we observe the presence of small-sized plants like Buglossoides arvensis $(15-50 \mathrm{~cm}$ high), Scleranthus annuus $(2-20 \mathrm{~cm})$ or Fumaria officinalis $(10-30 \mathrm{~cm})$, which could indicate harvesting using low sickle cuts. Thirdly, some arable weeds are characteristic of summer crop weed communities: Ch. album, Ch. hybridum, Fumaria officinalis, G. spurium, G. aparine/spurium, Polygonum aviculare, P. lapathifolium/persicaria and $S$. verticillata/viridis. Buglossoides arvensis and Valerianella dentata are characteristic of winter crop weed communities. A few can be found in both kinds of fields (Fallopia convolvulus, Papaver dubium, Scleranthus annuus, Vicia hirsuta and V. hirsuta/tetrasperma) (Ellenberg 1988; Julve 1998; Kreuz et al. 2005). According to these first results, we can assume that agropastoral communities of the Rhone valley favoured summer crops, without totally excluding winter cultures. Further analyses will clarify this aspect.

\section{Gathered plants and exploitation of territory}

Gathered plants are surprisingly very limited in our data set. This phenomenon is not due to preservation bias through charring, given that we have many other wild plants. Only quite a few shell fragments of hazelnuts $(n=241)$ were identified as well as isolated remains of wild pear, wild apple and elder. Fruits and berries of these forest edge species were probably gathered around the settlements, even if they can grow up to $1,500 \mathrm{~m}$ a.s.l. These rare finds of gathered plants lead us to a discussion concerning the occupation of the territory in this mountainous context. It is known that prehistoric alpine populations visited upland areas to exploit natural resources (flint, quartz, game, wild plants etc.), as soon as the retreat of the Würm glacier, around 17,000 вр. During the Neolithic, mountainous areas were also visited for pastoral 
purposes, in the form of seasonal nomadism (see e.g. Bintz and Griggo 2011; Mevel 2013; Walsh et al. 2007). In the Valais, during the Neolithic, almost all sites are located in the Rhone Valley. Occupations at high altitude-blockshelters and isolated finds-are very rare. These were visited by hunters, prospectors for raw materials and by shepherds, all probably moving between the bottom of the valley and the upper slopes (Curdy 2007). Here, archaeobotanical data show that subsistence strategies were based mainly on cultivated crops. We don't have any wild plants indicating that people were visiting higher altitudes, including the gathered plants cited before. If we compare our results with charcoal and faunal data, observations are similar. As an example, we use the site of "Petit-Chasseur" in Sion, from the level dated to $4000-3800$ cal BC. Here exploitation (firewood and timber) is principally axed on the collinean level, with the thermophile pine and oak forest and alder forest in the bottom of the valley. We have an economy based more or less exclusively on livestock farming, mostly sheep and goats, and almost no remains of game, especially from the higher areas, such as chamois and ibex. The plant macroremains assemblage is dominated by $99 \%$ of cereals (Chiquet 2011; Dufraisse 2011; Lundström-Baudais and Martin 2011).

A comparison can be made with other sites in the Northern French Alps, not far from the Valais, and during the Neolithic. We have identified numerous gathered plants and especially subalpine species (e.g. kernels of Pinus cembra, berries of Arctostaphyllos uva-ursi and of Vaccinium sp.). Archaeobotanical data indicate that Neolithic communities exploited different levels of vegetation, from the collinean to the subalpine belt. Hunting was also a widely practiced activity, especially during the Early and the Middle Neolithic (Martin 2014).

\section{Conclusion}

These first studies are about the plant economy of the first agricultural communities in Switzerland. They were growing mainly cereals, especially naked wheat and barley, as well as pea and poppy. The latter represent the first evidence in the Western Alps. Gathered plants are sparse and there are no signs of exploitation of higher areas. With the continuation of this project and these very encouraging first results, further analyses will give more data in order to understand:

(I) The evolution of cultivation and gathering in the region

(II) The relationship between the alpine population and the inhabitants of the plains, especially with regard to the Swiss plateau and Northern Italy
(III) The exploitation of the mountain territory

(IV) The status of different crops and especially of $P$. somniferum (ongoing archaeobotanical analyses of Neolithic sites of the Rhone valley will have to refine this aspect)

(V) Agricultural practices with more studies on arable weeds and ruderals.

Finally, these first results highlight specifically local farming practices and vegetal diet in the Valais, through comparison with other alpine and plain communities. This work shows the importance of continuing archaeobotanical analyses, especially in such contexts, where the potential of such studies is very great. On several sites, artefacts are badly preserved, and chronocultural information is incomplete. Archaeobotanical studies can reveal here precisely how, when and from where these first agropastoral communities settled in the Upper Rhone Valley.

Acknowledgments This study is part of a project called "First farmers in the Alps: an archaeobotanical approach on Neolithic agriculture and plant diet in Valais" supported by the Swiss National Science Foundation (Project no. PMPDP1_139632). I thank Dominique Baudais, Philippe Curdy, the team of ARIA in Sion, Alain Gallay and Marie Besse from the Laboratory of Prehistoric Archaeology and Anthropology of the University of Geneva, François Wiblé and the Service cantonal d'Archéologie du Valais, Stefanie Jacomet and Stephanie Thiébault for their support in this project. Patricia Vandorpe and Danièle Martinoli are gratefully acknowledged for their remarks and corrections.

\section{References}

Aeschimann D, Burdet HM (1994) Flore de la Suisse et des territoires limitrophes: le nouveau Binz. Éditions du Griffon, Neuchâtel

Baudais D (1995) Le camp néolithique de Savièse, La Soie. In: Gallay A (ed) Dans les Alpes, à l'aube du métal. Archéologie et bande dessinée. Musées cantonaux du Valais, Sion, pp 91-96

Baudais D, Schmidt P-Y (1995) Le site de Sion, La Gillière. In: Gallay A (ed) Dans les Alpes, à l'aube du métal. Archéologie et bande dessinée. Musées cantonaux du Valais, Sion, pp 97-102

Baudais D, Brunier C, Curdy P, David-Elbiali M, Favre S, Gallay A, May O, Moinat P, Mottet M, Voruz J-L, Winiger A (1989) Évolution du Néolithique de la région sédunoise (Valais central). Bull Murithienne 107:75-86

Baudais D, Brunier C, Curdy P, David-Elbiali M, Favre S, Gallay A, May O, Moinat P, Mottet M, Voruz J-L, Winiger A (1990) Le Néolithique de la région de Sion (Valais) Un bilan. Bull Cent Genev Anthropol 2:5-56

Bintz P, Griggo C (2011) Climats et premiers peuplements des Alpes du Nord françaises: des derniers chasseurs aux premiers paysans (15 000 à 5000 av. JC.). Revue de Primatologie 3:2-26

Buxó R (2007) Crop evolution: new evidence from the Neolithic of west Mediterranean Europe. In: Colledge S, Conolly J (eds) The origins and spread of domestic plants in southwest Asia and Europe. Left Coast Press, Walnut Creek, pp 155-171

Cappers RTJ, Bekker RM, Jans JEA (2006) Digital seed atlas of the Netherlands. Groningen Arch Stud 4. Barkhuis Publishing, Groningen, www.seedatlas.nl. Accessed 13 Oct 2014 
Chaix L (2008) Les animaux domestiques dans les Alpes occidentales au Néolithique. In: Jospin J-P, Favrie T (eds) Premiers bergers des Alpes De la Préhistoire à l'Antiquité, Musée Dauphinois. Infolio, Gollion, pp 53-61

Chiquet P (2011) La faune du Petit-Chasseur à Sion (Valais) revisitée. In: Besse M, Piguet M (eds). Un hameau du Néolithique moyen. Cahiers d'archéologie romande 124, Archaeologia Vallesiana 6, Lausanne, pp 217-254

Colombaroli D, Beckmann M, Van der Knaap WO, Curdy P, Tinner W (2012) Changes in biodiversity and vegetation composition in the central Swiss Alps during the transition from pristine forest to first farming. Divers Distrib 19:157-170. doi:10.1111/j.14724642.2012.00930

Corboud P, Rachoud-Schneider A-M, Studer J (2008) L'environnement. In: Gallay A (ed) Des Alpes au Léman. Infolio, Gollion, pp $15-46$

Curdy P (2007) Prehistoric settlement in middle and high altitudes in the Upper Rhone Valley (Valais-Vaud, Switzerland): a summary of 20 years of research. In: Della Casa P, Walsh K (eds) Interpretation of sites and material culture from mid-high altitude mountain environments. Preistoria Alpina 42, Trento, pp 99-108

Curdy P, Leuzinger-Piccand C, Leuzinger U (2003) Zermatt Alp Hermettji et les cols secondaires du Valais. In: Besse M, Stahl Gretsch LI, Curdy P (eds) ConstellaSion. Cahiers d'archéologie romande 95, Lausanne, pp 73-88

Denaire A, Doppler T, Nicod P-Y, Van Willigen S (2011) Espaces culturels, frontières et interactions au 5ème millénaire entre la plaine du Rhin supérieur et les rivages de la Méditerranée. Ann Arch suisse 94:21-59

Dufraisse A (2011) La composition des boisements et gestion du bois dans l'habitat néolithique moyen du Petit-Chasseur (Sion, Valais). In: Besse M, Piguet M (eds) Le site préhistorique du Petit-Chasseur à Sion (Valais, Suisse) 10. Un hameau du Néolithique moyen. Cahiers d'archéologie romande 124, Archaeologica Vallesiana 6, Lausanne, pp 269-278

Duke JA (1973) Utilization of Papaver. Econ Bot 27:390-400

Ellenberg H (1988) Vegetation ecology of Central Europe, 4th edn. Cambridge University Press, Cambridge

Finsinger W, Tinner W (2007) Pollen and plant macrofossils at Lac de Fully (2135 m a.s.1.): Holocene forest dynamics on a highland plateau in the Valais, Switzerland. Holocene 17:1,119-1,127. doi: $10.1177 / 0959683607082552$

Gallay A (2008) Des Alpes au Léman, Images de la Préhistoire. Infolio, Gollion

Gallay A, Carazetti R, Brunier C (1983) Le Néolithique ancien de Sion-Planta (Valais, Suisse). Vallesia 38:1-24

Haas JN, Richoz I, Tinner W, Wick L (1998) Synchronous Holocene climatic oscillations recorded on the Swiss Plateau and at timberline in the Alps. Holocene 8:301-309. doi:10.1191/ 095968398675491173

Heiri C, Bugmann H, Tinner W, Heiri O, Lischke H (2006) A modelbased reconstruction of Holocene treeline dynamics in the Central Swiss Alps. J Ecol 94:206-216. doi:10.1111/j.13652745.2005.01072.x

Jacomet S (2007) Neolithic plant economies in the northern Alpine Foreland from 5500-3500 cal BC. In: Colledge S, Conolly J (eds) The origins and spread of domestic plants in Southwest Asia and Europe. Left Coast Press, Walnut Creek, pp 221-258

Jacomet $S$ et al (2006) Identification of cereals remains from archaeological sites, 2nd edn. Archaeobotany Lab, Institut of Prehistory and Archaeological Sciences, Basel

Jacquat C (1988) Hauterive-Champreveyres, 1: Les plantes de l'âge du Bronze, catalogue des fruits et graines. Archéologie neuchâteloise 7. Ed du Ruau, Sainte-Blaise
Julve P (1998 ff) Baseflor. Index botanique, écologique et chorologique de la flore de France, http://perso.wanadoo.fr/philippe.julve/ catminat.htm. Version 2012

Kohler-Schneider M (2007) Early agriculture and subsistence in Austria: a review of neolithic plant records. In: Colledge S, Conolly $\mathbf{J}$ (eds) The origins and spread of domestic plants in southwest Asia and Europe. Left Coast Press, Walnut Creek, pp 209-220

Kreuz A (2007) Archaeobotanical perspectives on the beginning of agriculture north of the Alps. In: Colledge S, Conolly J (eds) The origins and spread of domestic plants in southwest Asia and Europe. Left Coast Press, Walnut Creek, pp 259-294

Kreuz A, Marinova E, Schäfer E, Wiethold J (2005) A comparison of early Neolithic crop and weed assemblages from the Linearbandkeramik and the Bulgarian Neolithic cultures: differences and similarities. Veget Hist Archaeobot 14:237-258. doi:10. 1007/s00334-005-0080-0

Lundström-Baudais K, Martin L (2011) Les paléosemences des fosses néolithiques du Petit-Chasseur IV. In: Besse M, Piguet M (eds) Le site préhistorique du Petit-Chasseur à Sion (Valais, Suisse) 10. Un hameau du Néolithique moyen. Cahiers d'archéologie romande 124, Archaeologica Vallesiana 6, Lausanne, pp 261-267

Marinval P (2008) Les premières agricultures et l'alimentation végétale. In: Tarrête J, Le Roux C-T (eds) Archéologie de la France: Le Néolithique. Picard, Paris, pp 76-83

Martin L (2014) Premiers paysans des Alpes. Alimentation végétale et agriculture au Néolithique. "Table des Hommes". Presses Universitaires de Rennes and Presses universitaires FrançoisRabelais, Rennes, Tours

Martin L, Jacomet S, Thiébault S (2008) Plant economy during the Neolithic in a mountain context: the case of "Le Chenet des Pierres" in the French Alps (Bozel-Savoie, France). Veget Hist Archaeobot 17:113-122. doi:10.1007/s00334-008-0191-5

Martin L, Delhon C, Thiébault S, Pelletier D (2012) Plant exploitation and diet in altitude from Mesolithic to Neolithic: archaeobotanical analysis from a hunting camp in the Chartreuse massif (Isère, France). Rev Palaeobot Palynol 185:26-34. doi:10.1016/j. revpalbo.2012.07.011

Mevel L (2013) Magdalenian pionners in the northern French Alps, 17000 cal BP. Antiquity 87:384-404

Müller K (1995) Le site de Sion-Tourbillon (VS): nouvelles données sur le Néolithique ancien valaisan. Archéol Suisse 18:102-108

Peña-Chocarro L (2007) Early agriculture in central and southern Spain. In: Colledge S, Conolly J (eds) The origins and spread of domestic plants in Southwest Asia and Europe. Left Coast Press, Walnut Creek, pp 173-187

Reimer PJ, Bard E, Bayliss A et al (2013) IntCal13 and Marine13 radiocarbon age calibration curves $0-50,000$ years cal BP. Radiocarbon 55:1869-1887

Richoz I, Haas JN (1995) Flore et végétation sur le Plateau suisse et dans le Jura. In: Hochulis S, Niffeler U, Rychner V (eds) La Suisse du Paléolithique à l'aube du Moyen-Age: De l'Homme de Néandertal à Charlemagne. SPM II: le Néolithique. Société Suisse de Préhistoire et d'Archéologie, Bâle, pp 59-72

Rottoli M, Pessina A (2007) Neolithic agriculture in Italy: an update of archaeobotanical data with particular emphasis on northern settlements. In: Colledge S, Conolly J (eds) The origins and spread of domestic plants in Southwest Asia and Europe. Left Coast Press, Walnut Creek, pp 141-153

Salavert A (2010) Le pavot (Papaver somniferum) à la fin du 6è millénaire av. J-C. en Europe occidentale. In: Delhon C, ThéryParisot I, Thiébault S (eds) Des hommes et des plantes: exploitation du milieu et gestion des ressources végétales de la Préhistoire à nos jours. Anthropobotanica, Antibes, pp 3-15 
Walsh K, Mocci F, Palet-Martinez J (2007) Nine thousand years of human/landscape dynamics in high altitude zone in the southern French Alps (Parc National des Ecrins, Hautes-Alpes). In: Della Casa P, Walsh K (eds) Interpretation of sites and material culture from mid-high altitude mountain environments. Preistoria Alpina 42, Trento, pp 9-22
Welten M (1982) Vegetationsgeschichtliche Untersuchungen in des westlichen Schweizer Alpen, Bern, Wallis, vol. 95. Denkschr Schweiz Naturforsch Ges, Basel 